\title{
Non European Cultural Heritages in Poetry for Young People (In and Out of School)
}

\author{
Herencias culturales no europeas en poesía para jóvenes (dentro \\ y fuera de la escuela) \\ Herències culturals no europees en poesia per a joves (dins i fora \\ de l'escola)
}

\author{
María Luisa Alonso. University of Cambridge, United Kingdom. \\ dralonsosoroa@gmail.com
}

https://orcid.org/0000-0002-9078-6339

\begin{abstract}
Poetry can be especially well-suited to encouraging awareness, reflection and debate about cultural difference. This article reflects on poetry's overlooked suitability to engage young people in the expression of cultural difference in a progressively globalized world where cultivating cross-cultural understanding and tolerance needs to be at the top of our agendas

My research paid attention to the different forms that poetry can take when young audiences interact with it. I focused both in school poetry and in poetry that circulates outside the straightjacket of formal educational contexts. The main body of this article focuses on literary qualities of texts but the first sections summarize the theoretical lenses that informed my investigation and the rationale that I used. I also include in this article, after an explanation about literary features in poems, a summary of the reflections that emerged from the analysis of printed and digital material and in conversations with interviewed key informants.
\end{abstract}

Keywords: Postcolonial poetry, Cultural difference, poetry and youth, poetry in performance

\section{Resumen}

La poesía puede ser muy adecuada para incentivar la conciencia, la reflexión y el debate sobre la diferencia cultural. Este artículo reflexiona sobre la adecuación para comprometer a los jóvenes en la expresión de la diferencia cultural en un mundo progresivamente globalizado en el que el cultivo de la comprensión intercultural y la tolerancia necesita prioridad.

Nuestra investigación presta atención a las diferentes formas que puede tomar la poesía cuando las audiencias jóvenes interactúan con ella. Focalizamos tanto en la poesía escolar como en la poesía que circula al margen de la camisa de fuerza de los contextos de educación formal. El cuerpo principal de este artículo focaliza en las calidades literarias de los textos, pero los primeros apartados resumen los enfoques teóricos que avalan nuestra investigación y la lógica que se ha utilizado. También se 
incluye en este artículo, tras una explicación sobre los rasgos literarios de los poemas, un resumen de las reflexiones que surgen del análisis de material impreso y digital y en conversaciones con informantes clave entrevistados.

Palabras clave: poesía postcolonial; diferencia cultural; poesía y juventud; poesía en performance

\section{Resum}

La poesia pot ser molt adequada per a encoratjar la consciència, la reflexió i el debat sobre la diferència cultural. Aquest article reflexiona sobre l'adequació per a comprometre els joves en l'expressió de la diferència cultural en un món progressivament globalitzat on el conreu de la comprensió intercultural i la tolerància necessita ser prioritària.

La nostra recerca para atenció a les diferents formes que pot prendre la poesia quan les joves audiències interactuem amb ella. Focalitzem tant en la poesia escolar com en la poesia que circula al marge de la camisa de força dels contextos d'educació formal. El cos principal d'aquest article focalitza en les qualitats literàries dels textos però els primers apartats resumeixen els enfocaments teòrics que avalen la nostra investigació i la lògica que s'ha utilitzat. També s'hi inclou en aquest article, després d'una explicació sobre els trets literaris als poemes, un resum de les reflexions que sorgeixen de l'anàlisi de material imprès i digital i en converses amb informants clau entrevistats.

Paraules clau: Poesia postcolonial; diferència cultural, poesia i joventut, poesia en performance

Intercultural dynamics - whether experienced as a condition of tragic mixture and alienation or as the comic integration of multiple strategies and sources - have fueled some of the most powerful poetry of our time

(Ramazani 2001, p. 7)

\section{Theoretical lenses and context}

Postcolonial theory and debates framed my research design. The postcolonial debate about children's literature has been mostly limited to fiction. This situation could be contested given the relevance of poetry within literature and within the global education of individuals. Postcolonial approaches to mainstream poetry are scarce and the few existing book-length studies about the particular literary qualities of poetry that can be explored from a postcolonial perspective do not focus on poetry for young people. Ramazani (2001) states "postcolonial studies and poetics offer a potentially valuable blend of strategies for exploring (an) important

\author{
Postcolonial approaches \\ to mainstream poetry are \\ scarce and the few \\ existing book-length \\ studies about the \\ particular literary \\ qualities of poetry that \\ can be explored from a \\ postcolonial perspective \\ do not focus on poetry for \\ young people.
}


and varied body of work" p. 4). Demonstrating a postcolonial approach to poetry for young people works with the disruption of many conventions prevailing in mainstream school approaches and dominant poetry culture. A postcolonial approach is interested in how poetry deploys different aesthetic or discursive elements as a means of challenging the dominance of Western linguistic and aesthetic patterns, models, ideas and ways of understanding the world. A postcolonial lens emphasizes how the poem "seeks to disentangle itself from disciplinary norms conducive to perpetuating cultural domination" (Ramanazi, 2001, p. 165).

I chose a comparative analytical design that is in line with current trends in international education research to highlight the usefulness of comparative approaches in "challenging the dominance of prevailing discourses about what is desirable and how it might be best achieved" (Broadfoot 2000, p.369). I collected and analyzed information from parallel cultural and educational contexts, France and Spain, "two countries whose common location within Europe and historical interconnectedness would suggest many similarities" (Broadfoot 2000, p. 362). This includes being marked by a significant colonial past. Different types of colonialism produced different kinds of unbalanced social relations between creoles, mestizos (mixed-race) and other indigenous groups that are deeply inscribed in current internal social exclusions and have global consequences in today's migrant world. Diverse social processes and socioeconomic situations in France and Spain have affected differently migrant people from cultures that have suffered colonial rule (and the way these differences are perceived by people in the former metropoles); in particular, my research took into account the different approaches to education in cultural diversity that are visible in the choice of poetry that has been made available to young people in the two countries.

\section{Research design and methodology}

The study was articulated through the interaction of three elements

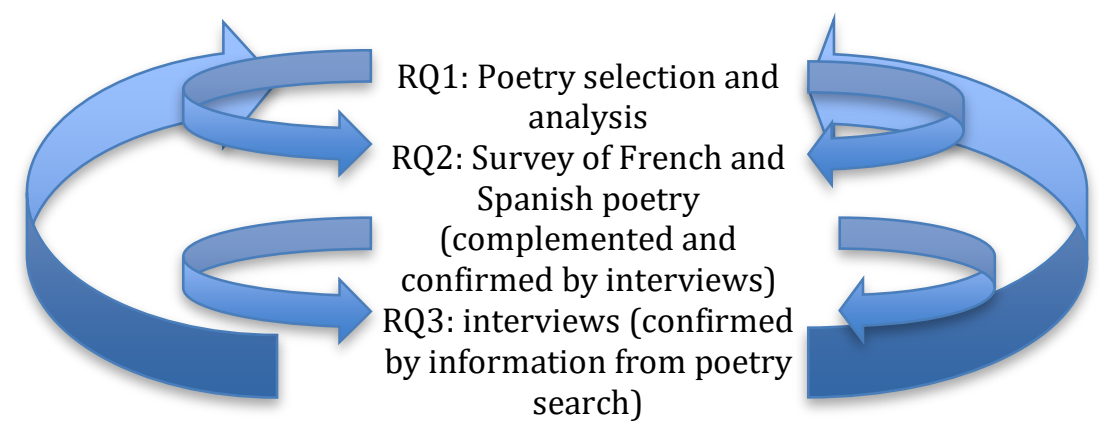

Figure 1. Research design 
1. Selection and analyses of a small sample of poems available for young people (2013-2015) to identify key characteristics which are distinctive to the poetry I was investigating. Rather than focusing on postcolonial poetry as a socio-literary category, I focused on a postcolonial approach to poetry that shares certain characteristics. This was illustrated through an analysis of poems, designed to bring out features that are often occluded when the poems are viewed out of context.

2. A two-stage investigation was conducted into which poems were available (and how they were made available) to young people in the respective countries both inside and outside formal education contexts. This encompassed investigating what poems with a postcolonial orientation were available for young people in different contexts, and what proportion or significance of the poems on offer articulated non-European cultural heritage First, searching for poetry in school education by exploring textbooks and anthologies. Secondly searching outside formal education. exploring on-line channels and exchanging information with relevant actors and organizations involved in France and Spain in the dissemination of poetry among young people.

The information generated was mixed. One investigation comprised a collection of poetry information, namely lists of poems, names of poems, links with videos of poems and whole poems texts. The other brought together varied viewpoints from people engaged in poetry for young people. These emerged from communications with relevant agents and organizations (prior to interviews) and from observations collected in a research journal that documented my poetry search (e.g., about my attendance at events like book fairs).

3. Interviews with experts (key informants) who have responsibilities within the institutional apparatus for the dissemination of poetry amongst young people. The development of this third methodological element entailed the selection of representative French and Spanish agents who were currently involved in the selection, production and distribution of poetry among young people. The information generated consisted in interview transcripts. The interviews sought to understand the positions of the interviewees with regard to the priorities, attitudes and concerns that guide their selections of poetry and of cultural interventions or pedagogical approaches to poetry for young readers.

A description of the methods used to identify poems as a way to investigating what poems with a postcolonial orientation were available for young people in different contexts is included in the following paragraphs. Also, a discussion about the observations of poetry searches is summarized in the following pages. This discussion is informed by the reflections and discussions that emerged in interviews with key informants. The three methodological elements that 
formed the research design were interrelated and helped me build my contribution to knowledge about poetry, young people and intercultural issues

\section{The methods used to identify poetry}

To investigate the availability of poems with a postcolonial orientation in the school context I studied the poems that were present in a sample of textbooks and recommended anthologies (2015) and focused on the poets' origins and expressions of multiple cultural heritages. I used one textbook per secondary school year per context and five recommended anthologies in French and in Spanish.

For the selection of school textbooks and anthologies, I tried to use a sampling strategy in which units were chosen based on how representative of the population they were (Schwandt, 2001, p. 232). The units of the sample were Spanish and French school textbooks and poetry anthologies currently used in the French and Spanish education systems. I selected textbooks and poetry anthologies used in schools following the instructions of the French and Spanish education systems.

The sample of school syllabi was composed of one French and one Spanish textbook per year of secondary education. However, I took into consideration the fact that, in the French and Spanish schools (Licée Francais and Spanish section of European schools) where the books that were available to me were being used, the last two years share the same syllabus. I therefore had access to a total of twelve syllabuses, with six per language. In the next phase of sampling strategy, I complemented the officially specified poetry selections with a search for official recommendations by relevant French and Spanish literary organizations. I searched for anthologies that can be seen as representative of mainstream practice because they are reviewed and endorsed by institutions frequently consulted by different agents (teachers included) who mediate between young people and literature. The aim was to find coincidences between the poetry included in school textbooks that could be read using a postcolonial approach and the poetry recommended by institutions.

For the selection of poems from outside of the school context I concentrated on searching for poems whose forms and strategies differ from what the main cultural gatekeepers have traditionally associated with school practice. I focused on non-written forms of poetry, taking into account the fact that non-written poems were missing in the school textbooks and anthologies that I considered. 
There are many existing possibilities for young people to engage with poetry forms that reflect the cultural heritages of European citizens of non-European descent in out-of-school contexts. However, there is a total absence of reliable and concrete indicators ${ }^{1}$ that could measure young people's current engagement with contemporary poetry forms outside school or in general cultural life. Therefore, when searching for poetry through informal learning contexts, the interest lies in the difficulty of delimiting the search for information in ways that are fruitful and illustrative for the investigation.

I used parameters similar to those used when filtering school poetry: I looked for French and Spanish speaking poets from non-European cultural backgrounds. I searched in different locations such as performance venues and especially in online channels. Young people commonly use these because they offer the easiest access to French and Spanish speaking poets from non-European cultural backgrounds that participate in Spanish and French performance venues. The performances that I filtered were poems that I could find using online channels commonly used by young people to participate in cultural life. It is through the Internet that young people can gain the easiest access to different kinds of poetry through the many platforms and online resources with which they interact on a daily basis. Using Internet resources took into account my convenience as researcher (e.g., it offered the possibility of accessing multiple digital recordings of performances without the need to travel to distant geographical locations), while also serving as an acknowledgment of the learning modes that are more characteristic of the new millennium and that are used by young people to engage with cultural and social life.

I concentrated on selecting contemporary poets who were currently active and whose creations were available at present through online channels (online poetry communities, video platforms, blogs etc.). It might seem that children tend to become less enthusiastic about poetry as they grow older but the case of the spoken word as a global phenomenon is worth paying special attention to as it is growing in popularity in youth cultures. I did not focus on poetry in song but I considered that poetry in performance takes different forms, in many of which the poetry recitation takes place with musical accompaniment. Poetry performed in different venues is usually registered and the videos commonly uploaded to online global video platforms or channels like YouTube, Dailymotion or Vimeo. They are then linked to the Internet pages or online social network profiles of slam communities and to the personal online sites or online profiles of the poets. However, I could only explore a small number of existing possibilities in

\footnotetext{
${ }^{1}$ My observations and communications with people involved with poetry venues and Internet platforms made me suspicious of the reliability of quantitative indicators such as numbers of visits and 'likes' in posts on online networks and Internet video platforms.
} 
young people's engagement through the Internet because its vastness and openness makes any ambition to representativeness impractical.

A useful strategy for selecting meaningful paths to survey poetry in performance using online channels was supported by the guidance of informed agents who knew about the production of poetry through different venues and about the dissemination in these channels. During a first preliminary stage I contacted organizers of poetry festivals and venues that were known to be popular among young people. The contacts that proved to be more helpful and comparable for my purposes were the Spanish and French federations of slam poetry. They were significant because they are active in social networks and well-informed about young people's engagement with contemporary practice. The French and Spanish slam federations can be seen as both catalyzers of poetry, because they group varied associations that help poets to make their poems public, and are also sites of exchange between poets, audiences and poetry event organizers. The slam federations were also relevant key informants for this research because they are aware of emerging practice that is being developed to bridge school practice and young people's participation in performed poetry events.

With the help of speakers from four slam organizations (two French and two Spanish) I obtained information about some poets from non-European backgrounds who participate in Spanish and French slam events. I also identified other interesting poets whose participation in local lives is remarkable and who perform poems in different venues but not necessarily with spoken word performances. I arrived at a selection of poems thanks mainly to the direct advice of people actively engaged in the organization of slam venues. These organizations pointed me in useful directions and led me to learn about many interesting digital recordings of performed poems, some of which were not recorded during slam venues. This was even the case for Lilian Pallares, a poet who has participated only occasionally (as opposed to Julian Delmaire who was and still is very active in the French slam scene) in slam venues in Spain but who is starting to receive credit in contemporary poetry milieus and is quite active with young audiences.

\section{Observations about poetry searches}

The selection of poems in school textbooks and school poetry anthologies produced in Western countries draws light on the way in which individual nation state curriculum histories, agencies and agendas are made material. These agendas convey a belief that this literature both represents and develops a shared cultural heritage. In my selection of school poetry, there were more poems written by Francophone poets from Africa or the Caribbean in the French syllabuses 
and anthologies than there were Spanish speaking poets from non-European backgrounds in the Spanish syllabuses. There were 366 poems in the Spanish and French textbooks and anthologies. Of 178 poems in the French school books, 14 were by Francophone poets from Africa and the Caribbean, a proportion of just under $8 \%$. In the Spanish case the proportion was even smaller, hardly $7 \%$. To put this proportion in its global context, there are 220 million French-speaking people of whom 44\% live in Europe (mostly in France, then Belgium and Switzerland), $46 \%$ in Africa and $10 \%$ in North America and the Caribbean region. This means a very limited representation of non-European cultural influences that have contributed to shape the French and Spanish nation's literary heritage. This also implies a poor presence in school materials of related language varieties. Additionally, the poems included in syllabuses that express nonEurocentric cultural heritages were likely to be those that could more easily be assimilated within a liberal multiculturalist paradigm.

While my searches showed that poetry articulating cultural difference is scarce in European schools, my searches in other learning settings confirmed that young people have access to it through other channels. In the UK, France and Spain young people engage frequently outside the school context with varied contemporary forms and their more frequent articulation of affiliation to English, French and Spanish speaking non-European heritages. In many European countries the number of live poetry performances, contests and festivals has increased significantly in the last decade. Internet (YouTube, Instagram etc.) has also made available a dynamic body of contemporary poetry, some of which has high quality and addresses intercultural issues in a performance mode that is highly engaging and accessible for young people. As a result, young people access easily and frequently, outside the constraints of educational institutions, varied forms of contemporary poetry ${ }^{2}$. The most accessible expressions have emerged from urban cultures, particularly syncretic ones, and take the form of poetry from performed venues like slam contests or verses from rap or hip hop lyrics.

Culturally syncretic expression circulates more freely in informal contexts, in the "many new forms of learning opportunity that characterize the third millennium" (Broadfoot 2000, p. 357). Much syncretic expression (that is considered poetry by some or which can be located in the blurred borders of the poetry field) is accessed (and many times reworked) by young people without adult mediation through virtual communities of peers and online social networks. In

\footnotetext{
2 Many of these forms are on the boundary between poetry and song or poetry and the spoken word; only some would be called poetry by most cultural and educational gatekeepers.
} 
addition to this, cultural organizations arrange activities for young people. In countries like France and the United Kingdom organized cultural events and activities that support the engagement of young people with mixed-heritage poetry are not uncommon. They import ideas from popular performance venues and forms such as slam poetry. However, in Spain the lack of a coordinated cultural strategy at National and regional levels that supports young people's engagement with poetry outside the school context make the efforts of a few cultural organizations look disperse and even more distant from the educational field.

\section{The recognition of literary qualities}

While I concluded that poetry articulating cultural difference has little presence in school contexts some commonalities of selected poems in the school sample lead to think about distinctive qualities and about some interesting issues that they foreground for young audiences, which are also present in out-of-school selected poems. The cultural and educational valorization of poetry entails the recognition of its literary qualities. Also, the cultural difference articulated by some poetry that is already present (if only scarcely) in school selections, may need attention to the possibilities and qualities of poems. Dealing with intercultural issues in literary education includes paying attention to the qualities and forms that best invite an approach which can be especially well-suited to encouraging awareness, reflection and debate about cultural difference, and the kinds of challenges and experiences this approach offers for young people.

Some commonalities exist between French, British and Spanish poetry currently available for young people that make it suitable for a critical exploration of cultural difference. The following are the main qualities (summarized) that I identified in some poetry written and performed in French, Spanish and English. I illustrate these qualities with verses from poems currently circulating among young people both in the school context and in informal learning settings.

1. The use of distinctive words, images, stylistic devices and sound patterns to foreground idiosyncratic understandings of social constructs and to illustrate recurrent concerns is a common feature in the poetry I focus on. An example is how Mistral uses in La Extranjera (The Stranger) different features to highlight the contrasting ways of understanding the indigenous and barbaric world of "the stranger", as opposed to a westernized and civilized way of knowing and living. 


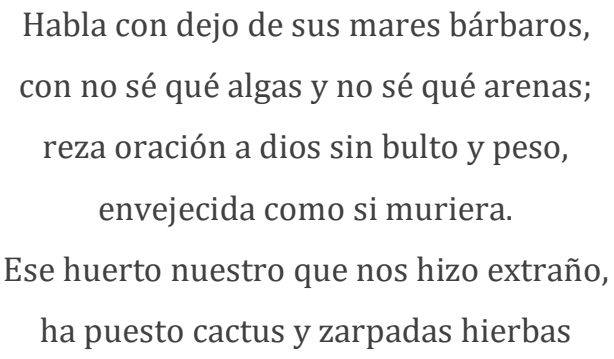

\section{English translation}

She speaks with neglect of her barbaric seas, With I don't know which algae and I don't know which sands; She prays to a formless, weightless god, Aged, as if dying In our kitchen garden that she turned strange She has planted cactus and thorny herbs.

Extract from La Extranjera by Gabriela Mistral

The epithet "barbaric" is used to describe the stranger's indigenous origins (and the poet's claimed roots) in opposition to the dominating westernized culture in Latin America. Several images illustrate a special communion between La Extranjera and the Earth and nature (cosmos included) that metonymically refers to an indigenous Amerindian understanding of life.

The following verses by Senegalese poet Leopold Sedar Senghor develop a staircase shape that enacts the leaping rhythm that the author intends to convey: the uncontrollable, vivid and abrupt call of Africa. The call of the tam-tam, an African percussion instrument that is similar to a gong, allegorizes Senghor's longing for Africa. This onomatopoeic "tam-tam" mirrors (in French) the sound that the instrument produces when it is played with the hands, and it also symbolizes the rhythm of Africa, mimetically representing the poet's African roots.

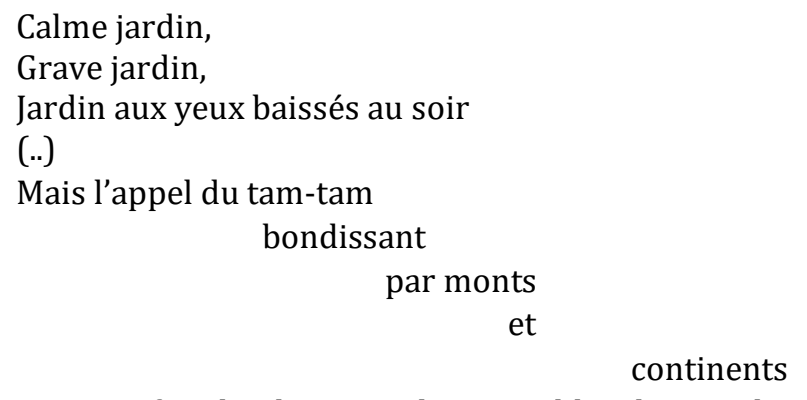

Extract of Jardin de France by Leopold Sedar Senghor 


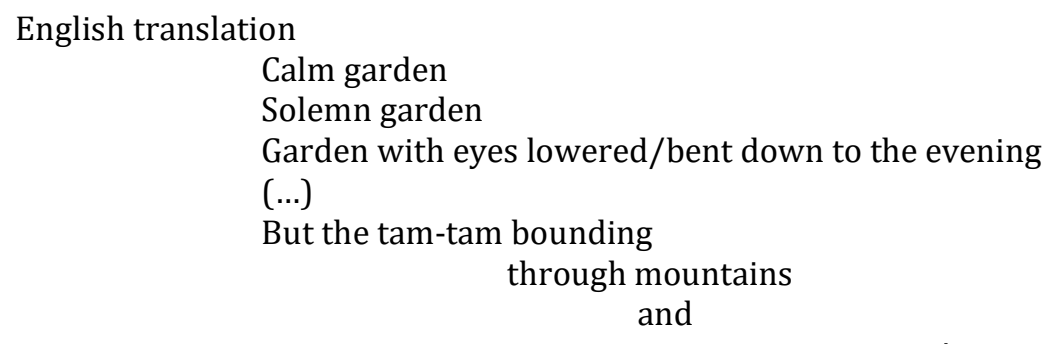

continents,

The central issue of the poem is the collision of two symbolic images. On one hand the garden, the poet's actual context, symbolizes France and a Western way of understanding the world. On the other hand, the tam-tam symbolizes Africa and materializes Senghor's nostalgia. It is the dialogic co-occurrence of these two central figures which constructs the strength of Jardin de France.

More contemporary than Mistral's and Senghor's are the following verses by Spanish speaking Caribbean poet Lilian Pallares:

\section{English translation}

$$
\begin{aligned}
& \frac{\text { Cabellos de palma }}{\text { Agua de coco }} \\
& \text { Y oleaje perpetuo } \\
& \underline{\text { Cabellos marinos }} \\
& \text { Afrodisiacos } \\
& \text { Y de algas flotantes }
\end{aligned}
$$

\author{
Palm tree hairs \\ Coconut water \\ And perpetual swell \\ Sea Hairs \\ Aphrodisiac \\ And of floating seaweed
}

Extract of Iniciación by Lilian Pallares

The central figure of the previous verses, the hairs, not only distil the poet's essence but also evoke a feminine collective spirit. The image of the hairs enacts an erotic feminine power, a "vitalist version of spiritual issues" (Tena 2010) that can best be expressed through poetic means. Lilian's feminine style is in line with claims by other contemporary female poets like Gioconda Belli: who opposes the existential depth of sensual Latin American idiosyncrasy to stereotypically colorful but superficial folkloric representations of Latin American cultures. Pallares attaches to the symbolic image of her hairs intertwined qualities. These juxtapose canonical Western symbols on the kind of feminine connection to natural elements that dominates the poem. A feminine connection to natural elements is sublimated in the AfroCaribbean tradition of female transition that the theme of the poem focuses on.

Guyanese poet Grace Nichols also draws on her Afro Caribbean heritage. She makes it visible and audible in the choice of images and patterns: 
Come on into my tropical garden

Come on in and have a laughing

Taste my sugar drink and my pine cake

Come on in please come on in

And yes you can stand up in my hammock

And breeze out in my trees

And you can pick my hibiscus

And kiss my chimpanzees"

Extract of Tropical Garden by Grace Nichols

2. The need to express a sense of cultural displacement or contrast and the longing for a distant land related to the poet's roots is a common feature in poetry for young people that is worth of attention and commentary. Cultural products (poems included) make visible the ways in which different groups of people who have suffered (or were born) the aftermaths of colonial encounters represent themselves, how they represent their conformity or disagreement with regard to the assimilation of Westernized universal patterns, how they perceive themselves and how they feel themselves to be perceived by peoples in the old settler communities.

The following verses, from La Extranjera, are relevant here

Alienta del resuello del desierto y ha amado con pasión de que blanquea, que nunca cuenta y que si nos contase sería como el mapa de otra estrella.

\section{English translation}

She breathes with the panting/gasping of the desert And she has loved with a passion that turns her white

that she never speaks of, for if she were to tell

It would be like the face of another star.

The verses that build La Extranjera seem to be brought to the page in the form of a list, an enumeration of claims to the strangeness of the subject (the mysterious stranger). A sequence of claims is divided into three parts of growing strangeness, a structure that progressively deepens and consolidates the division between our world and the stranger's.

While La Extranjera (found in a school anthology) was the expression of a Chilean poet who wrote at the turn of the XIX century, the following verses (found on a popular Facebook page) originally written in English by Chicano poet and activist Rodolfo Gorki González, similarly reveal 
how colonial encounters produced movements of people who express a sense of cultural displacement that persists through time and space. As postcolonial theorist Gayatri Spivak puts it "Whatever our view of what we do, we are made by the forces of people moving around the world." (2003, p.3).

I am Nezahualcóyotl, great leader of the Chichimecas.

I am the sword and flame of Cortes the despot And I am the eagle and serpent of the Aztec civilization.

Extract of I am Joaquín by Gorki

The following contemporary verses resonate with Gorki's and Mistral's poems. They are articulated (often in the form of poetry performance in Madrid) by Leo Zelada (Spanish resident born in Peru in 1970).

\author{
y no sé ahora en realidad \\ quién soy \\ si tal vez un incógnito \\ amauta \\ pronunciando alguna oración \\ oculta hacia el sol \\ o un oscuro corsario \\ asolando algún puerto \\ desconocido del sur \\ Extract of Machupichu by Leo Zelada
}

\title{
English translation
}

«and I don't know now

who I am

if I am an incognito 'anauta ${ }^{3}$

enunciating some concealed prayer to the sun

or a dark corsair

devastating any unknown port in the south »

3. The feelings associated with living in a liminal space of constant cultural negotiation are also frequently articulated by contemporary poets. It can also be found in the expression of a few poets who are, if only occasionally, sometimes included in school selections.

Exile is dealt with in the mentioned Mistral's La Extranjera as it is in Senghor's Jardin de France. While Senghor's poem inclusion in the poetry selections of French textbooks and anthologies is

\footnotetext{
${ }^{3}$ Inca wise person
} 
frequent, La Extranjera can only be found in a few Spanish recommended anthologies. In terms of formal strategies, the conflict in La Extranjera and Jardin de France is interesting as the poets frame it in ways that do not permit it to be easily assimilated or erased through absorption into universals. The more contemporary poem Wherever I hang, by Guyanese poet Grace Nichols resonate with Mistral's foregrounding of an impossibility of belonging.

To tell you de truth I don't know really where I belaang

Yes, divided to de ocean

Divided to de bone

extract from Wherever I Hang by Grace Nichols

Also, in Delmaire's contemporary poem (frequently performed on stage) Favela, Delmaire expresses and connects his own liminality with a global wound that is in this case represented by Brazilian favelas.

\author{
Ô Favela, Favela \\ Rythme de braise, cendre mystique \\ Voix portugaise, accent d'Afrique \\ extract from Favela by Julian Delmaire
}

\title{
English translation
}

Ô Favela, Favela

Ember rythm, mystic ash

Portuguese voice, African accent

Mistral, Senghor, Nichols and Delmaire manifest their subject position between two cultures. They also show a general interest in the cultural negotiations and positions of inbetweenness generated by global people displacements. This common concern frames the relevance of their poetry not only within their own local dimensions but also within a global design.

4. The poets' "social commitment to ethnic and cultural diversity with a specific desire to integrate different ethnic (mainly a mixed-race singularity) and cultural positions within a context marked by white male supremacy" (Author 2016) is also a common thread among poets who feel deeply affected by the difficulty of living between two different cultural perceptions of the world. Race is a central issue in Cuban Nicolas Guillén's poem La Muralla as it is in Martinican Césaire Aimé's Demain. 


\author{
différents à leur base \\ mais oh! \\ que leurs têtes se rejoignent oui très haut dans l'éther \\ égal à ne former pour tous \\ qu'un seul toit \\ je dis l'unique toit tutélaire... \\ English translation \\ different at their base \\ but oh! \\ may their heads meet yes high up in the ether \\ equivalent to forming for all \\ just one roof \\ I say the only protective roof... \\ Extract of Demain by Aimé Cesaire
}

Both La Muralla and Demain can be seen as odes to harmonious living between people of different ethnic origins, but the ambiguous feelings that emerge in multiethnic environments are made evident and help to illustrate the contradictory nature of Caribbean cultural hybridity.

Half Caste also by a Caribbean poet (John Agard) is a more contemporary poem. In this case the verses overtly approach the tensions inherent in dealing with racial purity and how people feel about it.

\author{
Explain yuself \\ wha yu mean \\ when yu say half-caste \\ yu mean when Picasso \\ mix red an green \\ is a half-caste canvas?
}

Extract of Half Caste by John Agar

Attention to literary qualities is best framed within the contexts of reception and production of the poems because "readings have status not objectively but relative to their circumstances" (Stockwell 2002:4). The context of reception is an issue in considering the relationship of the poems' content and form to young peoples' frames of reference. Paying attention to the context of poetry production means considering the historical and sociological contextualization of the poem's rhetorical strategies and the meaning that the poets deploy. This way of framing the discussion of poetry has relevant implications for how poems may be taught, or perhaps encountered, in a context of reception that is likely to yield maximum potential for an 
understanding of cultural difference that highlights the richness of varied cultural backgrounds and linguistic variations.

I observed in my research (i.e.: what I mentioned before about the presence of La Muralla's verses in one syllabus) that lessons in textbooks miss the opportunity to offer any hints of the poems' contexts of production. Following La Muralla example, a teaching strategy that enhances cultural difference would highlight how Guillen's engagement with Cuban ethnic and cultural diversity are articulated in the poem. Given the poet's personal ties to colonized territories and the relevance of his engagement with the Cuban cause, an introduction to the author could frame best an exploratory analysis that foregrounds Guillen's cultural position.

In poetry, the voice of the author has a distinctive personal connection with the production contexts of the poet and the text's intentionality. This is not necessarily shared to the same extent with other kinds of literary texts because "poetry is the literary genre where subjectivity is maximal" (Dessons 1995, p. 81). In the case of authorial performances of poems (such as Iniciación, Favela or Machupichu), the presence of the poet's persona constitutes an additional feature for the contextualization of poems. Some contemporary poets share the desire to claim and highlight the cultural richness of their indigenous roots (African, Caribbean, Andean), setting them in contrast to a dominating Eurocentric cultural context. In their own ways, and with the particularities of their own individual backgrounds, they articulate their personal ties to colonized cultures and this has an influence in the formal strategies of their writings and/or their performances at different levels.

Poets' performances usually help to contextualize their poems. This is the case of Delmaire's. Delmaire precedes his performances with a brief introduction to help young people locate the experience in a specific framework. In the performance of his poem Rouge, the poet explains to his audience the influence of Negritude poetry, particularly Aimé Césaire's ${ }^{4}$, in his work, not only from an aesthetic perspective but also from a moral and ethical point of view. As Delmaire acknowledges when he presents a digital video-recorded performance: Rouge is a "tribute to my first love in poetry which was the poetry of Negritude" 5 . Also, the poet explains that Rouge "talks a lot about percussion and roots".

The performance of poems such as Iniciación, Rouge or Whenever I hang, adds an interesting layer of meaning. The case of Pallares performance is worth mentioning.

\footnotetext{
4 "Césaire reste une boussole, une référence, un idéal" From his blog

5 "En hommage a mes premiers amours en poésie qui était justement la poésie de la négritude".
} 
Pallares' recitation style is not very dramatic or excessively theatrical but her performance adds corporality to a very sensuous poem. The poet makes use of her hands and body language in her recitation, mirroring the rhythmic clapping of the public gathered around the dancers during Bullerengue celebrations. Percussion instruments accompany most of Pallares' recitations of the poem Iniciación (mentioned before) but in some digital videos there is only the poet spontaneously accompanying her recitation with undulating gestures that allude to the movement of the young female dancers' dresses (pollerones). In so doing, the poet foregrounds the undulating rhythm also conveyed by words (e.g., "perpetual swell") and stylistic features in the poem. This demands an attitude of the reader that is grounded in the body in such a way that the experience of listening to the performed poem will leave an imprint on the audience that will influence any later reading of a printed version of Iniciación.

\section{Reflections about poetry for young people that emerged from poetry searches and in interviews with key speakers}

Some recurrent themes emerged in the process of delimiting poetry searches and when talking to key informants involved in the field of poetry. Decisions behind new poetry selections define the representation of poetry. Questioning what forms of poetry (digital, print, oral, performed) are missing in school challenge what the educational system defines as poetry. These issues fueled interesting reflections and discussions with people involved in the French and Spanish fields of poetry for young people that I framed into existing scholarly efforts.

Every attempt to define poetry can be challenged and those participating in debates about it only agree on that poetry is best defined by poems: "Poetry like landscape, like lyric water, is not a precise nor defined or immutable thing"(Jiménez 1975, p.150). My research highlighted how increasing young people's engagement with larger and more diversified poetry selections contributes to expanding what defines the field of poetry. Intercultural issues in literature are often associated with multilingual concerns because poetry particularly resists translation and linguistic barriers can complicate access to poetry from diverse cultural traditions ${ }^{1}$. However, the evolution of some languages (i.e.: French Spanish, Portuguese and English) spoken by inheritors of varied cultural traditions, bear witness to the variations of diverse cultural heritages. Linguistic variations constitute an important element for their literatures' vitality but my research showed that poetry made available for young people by the school context hardly reflects how non-European heritages energize European literatures and the notion of poetry. 
The need to reduce the distance between home and school as environments for poetry enjoyment has long been pointed out by scholars studying children's poetry (e.g., Styles 1998). In the case of older children and poetry, the gap that it would be interesting to bridge is between school as a learning setting and the channels of youth culture, which are both popular and contemporary. However, as Joseph Thomas claims, much of the literary study of literature for young people emerges from "theory that questions both the idea of literature (with a capital L) and the cultural assumptions that undergird such a category" and from the "refiguring of the canon such theories allow" (2007, p. 3). For that reason, I followed Thomas 'point of view during my research process trying to spur debate about the limits of literary study, particularly those between mainstream adult poetry and that engaged with by adolescents, and between the fields of literature and cultural and media studies.

Paying attention to the underused and unexplored educational potential of French and Spanish poetry currently available for young people is a matter of developing both poetry appreciation and critical understanding of cultural diversity. The critical understanding of cultural diversity might involve challenging pedagogical approaches that tend to either assimilate or erase cultural difference, or that reiterate positions in a cultural hierarchy and aggravate distinctions. Developing poetry appreciation in a wide sense might also involve challenging continuously the representation of poetry, including the question of what forms of poetry (digital, print, oral, performed?) help to define what the educational system defines as poetry.

Dominant French and Spanish approaches to poetry and limited poetry repertoires hinder the visibility of some contemporary forms of poetry and restrain the effectiveness of some poetry already present in mainstream poetry corpora. European educational systems largely ignore the potential of oral, digital and non-printed forms of poetry for school poetry, in textbooks and anthologies. In France and Spain young people are left to encounter these voices through social media and informal networks of influence.

The challenge is to bridge young people's encounter with a richness of poetry forms and cultural variations in informal settings and school teaching strategies and poetry selections. Given that adults dominate access to poetry for young people, it is not surprising that educators from different cultural traditions frequently note a resistance to poetry. In his influential text for poetry teacher training, A l'Ecole de la Poésie (1980), George Jean asked poetry teachers to consider adolescence as a stage of non-conformity where the established (literary) order is seen as boring and exists to be subverted. Following Jean's orientations and framed by cultural activities that are developed outside the school context, some practitioners are developing 
dynamic methods for working with performance-based poetry in informal learning workshops, but both aspects are relatively unknown in formal curriculum material.

\section{Conclusions}

The conclusions of my investigation showed that the theoretical concern for cultural diversity that traverses Western educational political discourses does not permeate the decisions that inform the dissemination of poetry among young people. Neither is it effectively translated into an intention to enrich and diversify cultural perspectives on poetry. The representation of nonEuropean cultural heritages in the literature curricula of England, France and Spain is weak, with Spain having the least visible representation in textbooks and school poetry anthologies, France demonstrating an emerging recognition of a need to attend to the problem and England disrupting a settled if somewhat static resolution (Author and Blake 2019). All three countries clearly need to recognize better the contributions of new citizens whose cultural traditions differ from existing dominant conventions. Selections of poetry for young people are stamped with an unchallenged desire for the reproduction of established cultural and educational conventions in these national contexts. This situation does not help to nurture a context that is open to contemporary poetry forms that bring rhythms and representations from non-European cultural backgrounds to European literature. It preserves unchallenged the prioritization of poetry's function in education as the quintessential expression of national high-brow culture.

A more contemporary vision of poetry selections and teaching strategies might encompass digital, print and oral cultures for the production, performance and enjoyment of poetry; more actively engage young people in writing and creating poetry, as well as reading it; and might bring colonial pasts into a more honest dialogue with postcolonial presents through the juxtaposition of different poets and poems. This presents a considerable challenge to the professional development of many teachers, but there is a substantial foundation of research informed practice to build on in the pioneering teacher professional development work of the (anglophone) Caribbean Poetry Project.

The efforts done by the Poetry Across Borders international team (at the faculty of Education, University of Cambridge), Julie Blake's research evidence and my own research clearly indicates that there is rich potential for a renewal of poetry education in the UK, France and Spain. This renewal will come by widening the cultural space within which young people might find a more personally meaningful path towards enjoyment and appreciation of a wide range of poetry. This widening of the cultural space represents a significant challenge to established practice in 
curriculum and pedagogy, one which "calls for new proposals for reading practices and alternative creations" (Bessière 2001, p.159).

\section{References}

Alonso ML and Blake J (2019). Poetry, Nation State Curricula and Diaspora. Caribbean Journal of Education. (In Print)

Alonso, M. L. (2016). Poetry for Young People and Cultural Imbalances. A postcolonial approach to the current situation in Spain and France (Doctoral thesis). https://doi.org/10.17863/CAM.16659

Bessière, J. (2001). Littératures Francophones et Postcolonialisme. Fictions de l'Interdépendance du Réel in J. Bessière and J.M. Moura Littératures Postcoloniales et Francophonie (pp 169-195). Paris: Honoré Champion

Broadfoot, P. (2000). Comparative Education for the 21st Century: Retrospect and Prospect. Comparative Education 36, 3: 357-371

Dessons G. (1995). Introduction a la Poétique: Approche des Théories de la Littérature. Paris: Dunod.

Jean, G. (1980). A l'Ecole de la Poésie. Paris: Retz

Jiménez, J.R. (1975). Crítica paralela. Madrid: Narcea.

Ramazani, J. (2001). The Hybrid Muse: Postcolonial Poetry in English. Chicago: The University of Chicago Press

Spivak, G. (2003). The Death of a Discipline. New York: Columbia University Press

Stockwell, P. (2002). Cognitive Poetics. An Introduction. London: Routledge

Styles, M. (1998). From the Garden to the Street. London: Cassell

Tena, V. (2010, December 2). Presentación del Libro Voces Mudas. Retrieved from http://www.lilianpallares.com/2010_12_01_archive.html

Thomas, J. (2007) Poetry's Playground. The Culture of Contemporary Children's Poetry Detroit: Wayne State University Press

How to cite this paper:

Alonso, M.L. (2019). Non European Cultural Heritages in Poetry for Young People (In and Out of School). Journal of Literary Education, (2), pp. 110-129. doi: 10.7203/JLE.2.15351 